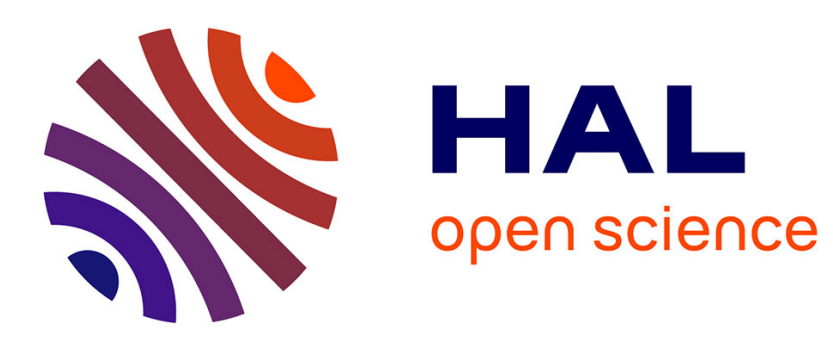

\title{
Coopetition between French healthcare providers: an analysis in terms of proximity
}

Anne Albert-Cromarias, Catherine dos Santos

\section{To cite this version:}

Anne Albert-Cromarias, Catherine dos Santos. Coopetition between French healthcare providers: an analysis in terms of proximity. Supply Chain Forum: An International Journal, inPress, pp.1-10. 10.1080/16258312.2020.1718547. hal-02513403

\section{HAL Id: hal-02513403 \\ https://hal.science/hal-02513403}

Submitted on 20 Mar 2020

HAL is a multi-disciplinary open access archive for the deposit and dissemination of scientific research documents, whether they are published or not. The documents may come from teaching and research institutions in France or abroad, or from public or private research centers.
L'archive ouverte pluridisciplinaire HAL, est destinée au dépôt et à la diffusion de documents scientifiques de niveau recherche, publiés ou non, émanant des établissements d'enseignement et de recherche français ou étrangers, des laboratoires publics ou privés. 


\title{
Coopetition between French Healthcare Providers: an Analysis in terms of Proximity
}

\author{
Anne Albert-Cromarias ${ }^{a *}$ and Catherine Dos Santos ${ }^{b}$ \\ ${ }^{a}$ CleRMa, Groupe ESC Clermont, Clermont-Ferrand, France, ${ }^{b}$ CleRMa, Groupe ESC \\ Clermont, Clermont-Ferrand, France \\ *Groupe ESC Clermont - 4 boulevard Trudaine - 63000 Clermont-Ferrand-France; e-mail : \\ anne.albert@esc-clermont.fr
}

\section{Introduction}

Coopetition - when organisations compete and cooperate simultaneously - is nowadays subject to an increasingly rich and rigorous literature that has structured this field for some twenty years now, gradually elevating this concept to the level of a theory (Fernandez et al., 2018, Gnyawali and Charleton, 2018). Although many aspects have been studied - antecedents, drivers, but also outcomes or tensions generated - (Dorn, Schweiger and Albert, 2016), coopetition has not yet focused on the territorial dimension that potentially structures its actors. However, the territory is often a key component for an organisation, both regarding resources (raw materials, labour...) and the Marshallian atmosphere that is sometimes found there, which is a real source of competitive advantage for the entire ecosystem. In addition, a territory appears to be a social construct and not just a spatial receptacle of activities (Pecqueur, 2015), making the territorial dimension of coopetition even more relevant to study, especially in a network approach (Dahl, Kock, and Lundgren-Henriksson, 2016; Mariani, 2016).We therefore focus on the role of the territory in coopetition, thus contributing to fill a theoretical and empirical gap. We propose to analyse it through different dimensions of 
proximity: geographical, cognitive, organisational, social, and institutional (Boschma, 2005).

We investigate the French healthcare sector, and more particularly the coopetitive relationships between healthcare institutions in the field of cancer treatment, in order to assess to what extent the territory influences the coopetitive relationships of these actors, or is influenced by them.

In the first part of this article, we show, through the literature on coopetition, how the territory constitutes a missing level of analysis; we will also present the specificities of the healthcare sector in terms of coopetition. The second part presents the context, the case study and the methodological framework of the research. The third part exposes our results through the five dimensions of proximity. Finally, the last part discuss the fact that coopetition is facilitated by the territory, while, at the same time, contributing to its development.

\section{Investigating the territorial dimension of coopetition through the healthcare sector}

\section{Towards a theory of coopetition}

Coopetition refers to situations where organisations are simultaneously in competition and cooperation. This subject is developing widely in international academic research. Initially approached as the convergence of interest between competitors (Brandenburger and Nalebuff, 1995), most often in a dyadic relationship (Bengtsson and Kock, 1999), coopetition is now being upgraded to a theory (Gnyawali and Charleton, 2018), thus explaining why companies involved in such relationships are successful (Fernandez et al., 2018). Moreover, coopetition appears to be a real coopetitive strategy than not just a phenomenon to be observed, or relationships between actors (Czakon, Klimas and Mariani. 2019). The literature has focused on many aspects of coopetition: its definition 
and characteristics, the nature of the relationships between the actors involved, the management of the paradoxical relationships induced, their antecedents and outcomes (Bengtsson and Raza-Ullah, 2016; Dorn et al., 2016), particularly in terms of innovation (Bouncken et al., 2018). The initial meaning of dyadic coopetition has also broadened considerably since the research addresses not only coopetitive relationships between direct competitors, but also vertical coopetition or even coopetition within heterogeneous groups of actors in a network (Czakon and Czernek, 2016; Dahl et al., 2016) or even in an inter-network logic (Mariani, 2016).

Obviously, coopetition generates both positive and negative outcomes, and tensions, too, at different levels: between organisations experiencing coopetitive relationships; or at an intra-organisational level, for those working within each organisation (Le Roy and Fernandez, 2015).

In order to address coopetition in all its complexity, it is necessary to integrate external factors and actors, i.e. not directly linked to the coopetitive relations themselves but exerting a positive (incentive) or constraining (pressure) influence on the actors to develop such strategies (Mariani, 2018). Based on the example of Finnish Lapland, Kylänen and Rusko (2011) thus show to what extent public authorities and their representatives play a decisive role in the formation and evolution of coopetitive relations between actors. Depending on the situation, coopetition may thus prove to be more or less intentional (Mariani, 2018).

\section{What is the role of the territory in coopetition?}

Despite this wide literature, what about the territorial anchoring of organisations that develop coopetitive strategies? As far as we know, no research is being done to find out whether it is easier (or on the contrary more difficult) for geographically close organisations to develop such relationships. This 'territorial' aspect of coopetition, 
which appears to us to be an important gap, remains unexplored by the few studies that address it in a derivative way. For example, Porto-Gomez, Aguirre-Larracoechea and Zabala-Iturriagagoitia (2018) focus on tacit coopetition - that is, between companies geographically located in the same region (Soubeyran and Weber, 2002) - and its impact on innovative performance, applying it to companies in the Spanish Basque Country. However, while they measure the different effects of tacit coopetition on companies, the authors do not explore the role of the territory as such.

This is probably because the actual definition of the notion of 'territory' raises questions, and because the literature on the subject is particularly vast and full of diverse disciplinary inspirations.

Interest in the territory is not new since Marshall, at the very end of the 19th century, pointed out its benefits in terms of positive externalities, highlighting the 'industrial atmosphere' that favoured the development of companies that are geographically close and belong to the same industry. However, the main stream of economic theory - particularly the industrial economy - is generally limited to considering the territory as an adjustment variable. Porter (1993) notes that globalization allows firms to find the necessary resources for their development through an appropriate geographical location, establishing the principle of nomadic enterprise. Research on clusters (Porter, 1998) or industrial districts, particularly in the Third Italy (Becattini, 1991), shows geographical proximity matters in terms of innovation, in the context of the Marshallese industrial atmosphere.

At the same time, in the 1990s, a 'school of proximity' developed in Europe, at the intersection between the industrial economy and regional sciences. It shows that while space matters, as evidenced by the many public policies based on localized innovation and learning regions (Florida, 1995), proximity is not only geographical, but 
could be decomposed into other forms of proximity. Thus, Rallet and Torre (2004) distinguish between geographical and organised proximity, while some add institutional proximity (Kirat and Lung, 1999), as Blanquart and Carbone (2014) did in their analysis of collaborative supply chain practices in this journal. Boschma's (2005) typology, initially applied to innovation, is nowadays the most used - that is why this is the one we will adopt for our study. It identifies five dimensions of proximity: cognitive, organisational, social, institutional and geographical (see Table 1). These different forms of proximity, which are essentially neutral and can be activated or not, but also intended or endured (Torre, 2010), lead to a dynamic definition of the territory: it is simultaneously understood as a process of territorialisation (and therefore coordination between actors) leading to relationships of territoriality (between actors who live there) (Pecqueur, 2009). According to Pecqueur (2015), the 'territory' exists when, in a given geographical context, actors meet, identify a common productive problem and set up a project to solve it. The territory thus proves to be a social construct, activating these different forms of proximity for and by all its stakeholders; it is therefore a decisive element of the organisation's strategy.

Table 1. Five Forms of Proximity

\begin{tabular}{|l|l|}
\hline Proximity Form & Key Dimension \\
\hline Cognitive & Knowledge gap \\
\hline Organisational & Coordination and control \\
\hline Social & Trust based on social relations (at the micro-level) \\
\hline Institutional & Trust based on formal (laws or rules) and informal (cultural \\
& norms or habits) institutions \\
\hline Geographical & Spatial or physical distance \\
\hline
\end{tabular}

Source: Boschma, 2005 
However, as already mentioned, research on coopetition has not, for the time being, addressed its territorial dimension. We are therefore questioning the role of the territory in coopetition, analysing it through the five forms of proximity (Boschma, 2005).

\section{Speaking of coopetition in healthcare}

The literature considers that coopetition depends on the industry and context in which it is studied, integrating the directionality of association and causality (Czakon et al., 2019). We choose to deal with the healthcare sector. In most developed countries, the healthcare industry is characterized by many reforms over the past twenty years, aimed at two simultaneous objectives: developing a public health policy aimed at the wellbeing of the population and the quality of care; and improving economic efficiency within a management logic of cost control. The environment appears dynamic and complex, because of the variety of stakeholders (health professionals - doctors, nurses and support services; private or public institutions; patients...), the pressure of regulatory authorities (van den Broek, Boselie and Paauwe, 2018) and networks between institutions (Chakraborty, 2018). In its proposal of an integrated healthcare supply chain model, Yanamandra (2018) shows that mutual trust and cooperation are necessary in order to achieve customer satisfaction and costs reduction.

Moreover, some studies give evidence that healthcare is experiencing coopetition (Barretta, 2008; Gee, 2000; Mascia, Vincenzo and Ciccheti, 2012; Peng and Bourne, 2009; Westra et al., 2017), confirming that social ties and trust really matter in network coopetition (Mariani, 2016). Therefore, by its specific nature, the healthcare sector appears to be a relevant field for studying network coopetition, particularly in its territorial dimension. Indeed, the question of access to care is crucial, making it essential that patients have a relative geographical proximity of facilities. 
In these conditions, our work consists in filling the gap in the literature, which does not take into account (or incidentally) the territorial dimension of coopetition. To do this, we study a network of healthcare providers, in the particular field of cancer treatment, located on the same geographical area. The coopetition at work between these institutions is then analysed through the five dimensions of proximity (Boschma, 2005) making the territory exist.

\section{The case of cancer treatment on a French regional healthcare area}

We focus our research on the coopetitive relationships between French healthcare providers in the field of cancer treatment on the same geographical area. After giving some background information about the main evolutions of the French health system and the context of cancer treatment in France, we explain the methodological framework for our research. Then we present the case-study.

\section{Context: the French healthcare system}

In most developed countries, reforms in healthcare system have oscillated, the past two decades, between two touchstones: the increasing involvement of public authorities in the management of healthcare establishments, and the market as the only means of coordinating actors. We are focusing on the case of the French health system that is relevant because, on the one hand, the OECD considers it at one of the best in the world and, on the other hand, recent successive reforms have led to major changes in the sector. The territorialisation of health policies thus becomes an instrument for reducing socio-spatial inequalities and costs, regionalisation being considered as a source of savings and of collaboration. French reforms have focused on sharing 
resources for institutions, particularly those that are scarce and/or expensive, encouraging networking and cooperation between actors. By having the freedom to choose, even if there are still inequalities particularly due to their geographical location or their social protection, patients are now stakeholders in their own care pathway. That means that healthcare providers have been obliged to review their strategies and make sure their services are as appealing as possible (Louazel and Keller, 2016). Pushed to compete with each other, providers now need to understand the characteristics and the trends of their population and environment in order to choose the best strategy for their development and future trajectory. They also need to increase their market share, whether by external or organisational growth. The challenge involves achieving a critical mass of activity that guarantees the profitability of the organisation, as illustrated by the trend in the concentration of private clinics and in the efforts to maintain the quality, qualifications and stability of medical teams.

Yet healthcare providers are established in geographical zones from which they draw in patients according to their specialties and specificities. Due to major regional and social healthcare disparities, and a pessimistic outlook in terms of medical demography, French hospitals have slowly, but surely, started to give more consideration to the health, socio-economic and even cultural characteristics of the regional healthcare areas they serve. These areas are structured around the presence of facilities and providers, to whom are given fixed healthcare targets according to the demographic, social, epidemiological and geographical characteristics of the region. They have also been designed to be a forum for dialogue between local actors, and to enable a clear regional medical project to emerge, involving a variety of activities and levels of healthcare. The organisation of regional healthcare areas simultaneously relies on an administrative approach (which pre-existed since 1970 through the healthcare 
map); the local population living habits ('life spaces'); and existing infrastructure ('service spaces') (Bourdillon, 2005). This organisation clearly involves a dimension of geographical proximity triggered by the links forged by local stakeholders (Torre, 2010). Therefore, the regional healthcare area appears to be at the same time a regulatory space (through the Regional Healthcare Plan), a space for competition (in the context of a quasi-market) and a space for cooperation (encouraged and even enforced by the public authorities) (Louazel and Keller, 2016).

\section{The specificities of the cancer treatment field}

In France, nearly 400,000 new patients suffering from cancer are detected each year, and more than 150,000 die of it; it is the number one cause of mortality in the country ${ }^{1}$. Due to the increase in new cases and improved survival, the total prevalence of cancers has increased in 2017 with 3.8 million people affected (the prevalence accounts for the number of living people diagnosed with cancer during their life). 1.2 million people are hospitalized for the diagnosis, treatment or monitoring of cancer in 2017, an increase of $10 \%$ compared to 2012 .

Cancer activity (i.e. surgery, chemotherapy, and radiotherapy) represents almost a quarter of global hospital activity: $48.8 \%$ of sessions, $9.8 \%$ of ambulatory hospitalizations and $13.8 \%$ of full hospitalizations. 877 establishments are authorized to perform cancer treatment: public healthcare providers (University Hospital Centres CHU - Centres Hospitaliers Universitaires, or Hospital Centres - CH - Centres Hospitaliers); private institutions (clinics) ; Public Interest Private Healthcare

\footnotetext{
${ }^{1}$ All figures are provided by the National Institute for Cancer (InCA): https://www.ecancer.fr/Expertises-et-publications/Catalogue-des-publications/Les-cancers-en-Franceen-2018-L-essentiel-des-faits-et-chiffres-edition-2019; accessed 11 February 2019
} 
Institutions (ESPIC - Etablissements de Soins Privés d'Intérêt Collectif), which are Cancer Control Units. The Regional Health Service (ARS - Agence Régionale de Santé) issues permits to providers, fulfilling the technical conditions and the relevant permission for the activity, and who, in addition, are official members of a cancer treatment network.

Several sets of government measures are taken since 2003 through successive Cancer Plans. For the period 2014-2019, it aims to mobilize the whole range of available means of health intervention, from research through to treatment, in order to cope with inequalities in health and reduce avoidable cancer mortality rates ${ }^{2}$. One objective in the plan (number 16) particularly aims to improve the efficiency of organisations. Amongst other goals, one is to redefine the role of regional and local actors in how they support the Regional Health Service, including two actions that require a review of the organisation of cancer healthcare providers. First, by focusing on collaborations between organisations, ensuring that the Regional Health Service receives strong regional support in the field of cancer care [action \#16.4]; Second, by structuring the regional care system around the objective of providing a continuous and comprehensive healthcare service [action \#16.5].

\section{Methodological framework for the research}

Within this context of the championing of cooperation between healthcare providers through 'collaborations between organisations' and 'the structuring of the regional care system', we are particularly interested in understanding what role the territory, analysed according to the five dimensions of proximity (Boschma, 2005), plays in coopetitive

\footnotetext{
${ }^{2}$ http://solidarites-sante.gouv.fr/IMG/pdf/2014-02-03_Plan_cancer-2.pdf; accessed 11 February 2019
} 
relations. We use a single case study (Yin, 1999) through a comprehensive research method (Dana and Dumez, 2015: 157), 'taking into account what [the actors] say of what they do and the fact that they are knowledgeable agents'.

This study involved desk research and 25 semi-structured interviews from different local providers, conducted between September 2016 and November 2017. The sampling of these interviews was carried out in such a way as to be representative of the different providers (see Table 2). The guide map was made up of three broad themes: cooperation; competition; regional healthcare area. Each interview lasted between 45 and 90mn. All interviews were recorded, transcribed and then exploited through vertical and horizontal thematic analysis, thanks to our analytical framework. The final number of interviews was given by saturation of the collected information.

Table 2. Interviews

\begin{tabular}{|l|l|r|}
\hline Employee Category & Interview references & Number \\
\hline Doctor & $1 ; 6 ; 7 ; 12 ; 19 ; 21 ; 25$ & 7 \\
\hline Nursing staff & $3 ; 4 ; 9 ; 10 ; 14 ; 16 ; 17 ; 20 ; 22$ & 9 \\
\hline Support services & $2 ; 5 ; 8 ; 11 ; 13 ; 15 ; 18 ;$ & 7 \\
\hline Outside experts & $23 ; 24$ & TOTAL \\
\hline & & 25 \\
\hline
\end{tabular}

Source: authors

\section{Presentation of the studied area}

Our case study focuses specifically on the healthcare providers for cancer treatment in the old Auvergne region, in the middle of France. Currently, in that place, 19 institutions are authorized to perform cancer surgery and/or radiotherapy and/or chemotherapy, and, in total, 35 are able to provide treatment for cancer patients (e.g. home care or small hospitals). 
Founded in 1973, the CCU is located on the site of the local University Hospital Centre (CHU), with which it shares a public service mission. Since its creation, the CCU has had a complex relationship with its partner, marked by a persistent fear of being taken over. Locally, there are two big private clinics too; one ('Clinic 1') founded in 1987 and the oldest ('Clinic 2') founded in 1974. These four actors clearly dominate. The $\mathrm{CHU}$ is the leader in terms of the number of interventions, followed by the $\mathrm{CCU}$ and then the two private clinics (see Table 3). However, one of the particularities of cancer treatment is that strong specialties exist from one institution to another. On the one hand, equipment is sometimes unique locally (depending on the authorizations granted by the Regional Health Service; for instance, the CCU is the only one to perform radiotherapy). On the other hand, the reputation of some oncologists (for example on breast cancer: the CCU and Clinic 1) sometimes makes a difference.

Table 3. Volume of activity of the main local healthcare providers (2016)

\begin{tabular}{|l|l|l|l|l|}
\hline & \multicolumn{4}{|l|}{ Number of Obstetric Operations and Treatment (MCO)3 } \\
\hline & CHU & CCU & Clinic 1 & Clinic 2 \\
\hline Total & 120352 & 54268 & 35510 & 32566 \\
\hline Examples of Cancer Treatment & \multicolumn{5}{l|}{} \\
\hline Pneumology & 446 & 978 & 58 & 4 \\
\hline Digestive tract & 625 & 114 & 109 & 68 \\
\hline Mammology & 358 & 1241 & 1043 & 347 \\
\hline Thyroid & 228 & 347 & 58 & 3 \\
\hline Urology & 337 & 36 & 46 & 101 \\
\hline Gynaecology & 1280 & 225 & 174 & 981 \\
\hline Chemotherapy & 19494 & 11985 & 11399 & 985 \\
\hline Radiotherapy & - & 13335 & - & - \\
\hline Source: ATH, Scan & & & & 3 \\
\hline
\end{tabular}

Source: ATIH, ScanSanté Casemix MCO data

${ }^{3}$ MCO: Obstetric Medicine and Surgery, including out-patient services and cancer surgery. 
Over the last three years, the local environment has brutally changed. For example, the CCU had a relatively hostile relationship with the CHU; worked reasonably well with one private clinic (Clinic 2), which does not have a radiotherapy service; and clashed with the other big private clinic (Clinic 1), which has oncologists and performs breast surgery. Three years ago, the project of Regional Hospital Consortium reinforced the authority of the $\mathrm{CHU}$ in the region. Furthermore, as Clinic 1 was owned by a large national company and Clinic 2 was owned by a separate one, both were taken over, in 2017, by the leading French clinic group. These events have significantly altered the local context, since one sole stakeholder now owns the two major private clinics in the area.

\section{Coopetition between healthcare providers from a proximity perspective}

This case study enables us to identify the coopetitive relationships amongst cancer treatment providers in our local area and to analyse them thanks to the different dimensions of proximity according to Boschma (2005). We present our main findings in Table 4 and illustrate them through verbatim.

Table 4. Findings: Coopetition through the five dimensions of proximity

\begin{tabular}{|l|l|l|}
\hline & \multicolumn{1}{|c|}{ Coopetition } \\
\hline \multirow{2}{*}{$\begin{array}{l}\text { Geographical } \\
\text { proximity }\end{array}$} & \begin{tabular}{l}
\multicolumn{1}{|c|}{ Competition } \\
and permits from the Regional \\
Health Service
\end{tabular} & \begin{tabular}{l}
\multicolumn{1}{c|}{ Cooperation } \\
local scale according to patients' \\
needs
\end{tabular} \\
\hline $\begin{array}{l}\text { Cognitive } \\
\text { proximity }\end{array}$ & $\begin{array}{l}\text { Usual barriers between providers } \\
\text { ('small' vs. 'big' / 'public' vs. } \\
\text { 'private') }\end{array}$ & $\begin{array}{l}\text { Research, skills and resources in } \\
\text { accordance with the patient }\end{array}$ \\
\hline
\end{tabular}




\begin{tabular}{|c|c|c|}
\hline & & $\begin{array}{l}\text { pathway in order to ensure } \\
\text { quality of care }\end{array}$ \\
\hline $\begin{array}{l}\text { Organisational } \\
\text { proximity }\end{array}$ & $\begin{array}{l}\text { Enforced partnerships } \\
\text { strengthening rivalry } \\
\text { The law of the jungle }\end{array}$ & $\begin{array}{l}\text { Reaching a critical mass to } \\
\text { optimize major (and expensive) } \\
\text { pieces of equipment } \\
\text { Organising a complementary of } \\
\text { services between providers }\end{array}$ \\
\hline $\begin{array}{l}\text { Social } \\
\text { proximity }\end{array}$ & $\begin{array}{l}\text { Three different social worlds } \\
\text { (physicians, nursing staff, } \\
\text { support services) } \\
\text { Distinction between hospital (or } \\
\text { clinic) staff and GPs }\end{array}$ & $\begin{array}{l}\text { Partnerships exist thanks to } \\
\text { some leaders (among surgeons } \\
\text { or top managers) }\end{array}$ \\
\hline $\begin{array}{l}\text { Institutional } \\
\text { proximity }\end{array}$ & $\begin{array}{l}\text { The managerial approach to cost } \\
\text { control and the need for } \\
\text { performance encourage } \\
\text { stakeholders to "everyone for } \\
\text { itself" }\end{array}$ & $\begin{array}{l}\text { The traditional values of charity } \\
\text { lead to focus on the quality of } \\
\text { care, whatever the scale or the } \\
\text { partner }\end{array}$ \\
\hline
\end{tabular}

Source: authors

\section{Coopetition at a geographical scale}

The geographical dimension of proximity, defined by Boschma as 'the spatial or physical distance between economic actors, both in its absolute and relative meaning' (2005: 69), is present in its purely spatial sense, as evidenced by the administrative definition of the health territory and the geographical proximity between establishments, all within a very limited radius of six kilometers. At first sight, the administrative definition of the regional healthcare area would appear to be rather narrow, understood, according to legislative texts, as 'an operating area that is basically very restricted' [14], with 'permission to treat patients delivered by the authorities' [16]. The French legal context, based on the territorial dimension in the spatial sense of the term, turned regional healthcare strategies into instruments for, both, reducing socio-spatial 
inequalities and costs and, at the same time, developing collaborations, thanks to, for example, the creation of Regional Hospital Consortiums based upon a shared regional medical project on 5 years. Therefore, this geographical meaning consists of 'identifying regions with coherent patient behaviour in terms of care needs and how to bring to this region, a local care service-if necessary a little further away for treatment requiring much more advanced technology.’ [5].

The NOTRe Act (New Regional Organisation of the French Republic) introduced in 2016 a new regional division that has become a powerful contextual factor, with both negative and positive impacts. From a negative point of view, there is the risk that the old regional capital city will become overshadowed by the new one ('We have gone from being a regional capital to a town with a university status that is weak and under threat. In this context, we find ourselves competing with Lyon, Grenoble and St Etienne [neighbouring cities]' [6]) and the risk that the decisionmaking bodies will be relocated ('Today, if you have a question for the [Regional Health Service], you have to go through Lyon [the current regional capital city]' [19]). From a positive point of view, there could be a reaction to the real or perceived domination of Lyon, so opportunities for regional actors in general ('Will this notion of a regional area be strong enough to unite the interests of one another, so that we restore a new balance?' [11]).

However, this static and restricted geographical vision gives place to much more open feelings, based on competitive and cooperative behaviours between providers: ' $I t$ ' $s$ above all about collaborating' [14]; 'We're regional, we must work for the region. The region makes obvious sense' [2].

\section{Beyond the geographical proximity: the other dimensions of coopetition}

Coopetition and cognitive proximity 
Defined as a 'shared knowledge base, in order to communicate, understand, absorb and process new information successfully' (Boschma, 2005: 64), cognitive proximity appears essential in the cancer treatment sector, whether in terms of research, skills or resources that the various actors agree to make available to the territory, in accordance with the patient pathway. 'It is absolutely essential for there to be collaboration between all of these structures because if there were to be clashes, then it would be one that harms the other and that is not in the interest of the patients' [13]. There is a clear consensus, indeed, on the absolute priority to be given to patients and the quality of their care. For the local institutions, 'the challenge involves getting over the usual barriers to develop a win-win project that involves grouping together non-competing activities' [23]. In other words, 'the objective must be to guarantee that the various actors in the patient care pathway will benefit from the development of cooperative partnerships, whilst at the same time placing the patient at the heart of their preoccupations, by making care cost savings thanks to the efficiency of the care pathway' [24].

\section{Coopetition and organisational proximity}

For Boschma (2005: 64), organisational proximity is the 'capacity to coordinate the exchange of complementary pieces of knowledge owned by a variety of actors within and between organisations'. Some fields such as research, which is vital for cancer treatment, are naturally much more open to cooperation. It is the same thing for the purchase of major pieces of equipment, for which the Regional Health Service issues permits and offers potential financing. This allows to reach a critical mass that optimizes the use of the equipment in order to meet the needs of the region: 'We have to 
make some very big investments. If we only use a machine at $60 \%$ of its capacity, then it makes sense to have a partnership' [8].

Partnerships are also set up quite naturally in efforts to establish a complementarity of services: '[With the CHU], we've got things to offer each other' [4]; 'There are specializations that the CHU doesn't have' [3], as for example with breast cancer, which the CHU does not treat, or for nuclear medicine for which the CCU has the local monopoly. Official agreements are drawn up to organize certain partnerships. For example, since 2006, there has been an outsourcing agreement between the CCU and Clinic 1, which allows an oncology surgery in Clinic 1, staffed by oncologists from the CCU.

Sometimes, partnerships 'are enforced, that is those for which we don't have our say, partnerships directed by the [Regional Health Service]. For example, we lost our flagship unit, the bone-marrow transplant unit, which was developed at [the CCU] and went to [one of the CHU entities]' [4]. It is worth mentioning the difficulty of actually putting collaborations into operation: '[The partner institution] gave a halfbaked answer: They are not against it, but we never seem to manage to find the right person to speak to' [11]. Finally, opportunistic behaviour exists too: 'When you think 'partnership', you think 'how can we gobble up the other?' [2].

\section{Coopetition and social proximity}

Social proximity, understood as 'socially embedded relations between agents at the micro-level' (Boschma, 2005: 66) is based on trust, loyalty and commitment. However, the healthcare sector is a complex one, made up of different social worlds that could be divided into three main categories: physicians, nursing staff, and support services, including top management: 'We work together, but there's still a divide' [3]. Beyond 
these real segmentations, linked to the qualification of individuals and their job and position in the hierarchy, some partnerships are developed thanks to some leaders, top managers and/or physicians: 'This agreement came about at the instigation of the surgeons [...] The objective was to guarantee a continuity of care and to not to have to send patients to another institution. It's a very good collaboration! Because in that system, everyone is satisfied' [20]. The role of GPs, who are not direct part from the studied institutions, is also highlighted: 'We will cooperate much better if the GPs are informed' [21].

\section{Coopetition and institutional proximity}

At the macro level, norms and values act as an institutional proximity, 'a sort of "glue" for collective action' (Boschma, 2005: 68). In the healthcare sector, original charitable values largely permeate behaviour ('A CCU should be able to treat everyone' [3]), regardless of the status of collective actors - private or public: 'In an establishment like ours, we shouldn't charge for private rooms' [9]. Doctors and caregivers clearly promote caring values ('Our charters suggest that charges shouldn't be borne by the patient, it's a value' [5]). These are squarely opposed to the quasi-market approach, even if it could be considered simply as an accounting exercise: 'We are compared to companies [...] but, today, behind that, we don't see patient-customer satisfaction. What we have seen is financial constraints.' [10]. However, these are generally regarded as legitimate: 'Profitability, the aim is to spend as little money as possible or as efficiently as possible. And to be able to meet the expectations of teams' [9], as long as the idea is not pushed to the extreme, or even the absurd: 'We need staff to meet certification requirements, but we were told this isn't possible because the [Regional Health Service] has told us to cut back on staffing!' [4]. 


\section{Discussion: Territory and coopetition as mutual catalysts}

In order to contribute to the coopetition literature, this research deals with its territorial dimension, analysed through proximity (Boschma, 2005). The five dimensions of proximity are clearly identified in the coopetitive relationships that cancer treatment actors have locally developed in recent years. Each form of proximity (geographical, cognitive, organisational, social or institutional) acts on the relationships between healthcare providers, whether they are competitive or cooperative, with positive or negative outcomes (see Table 4). This analysis leads to one major contribution: the territory, understood as the simultaneous presence of the five dimensions of proximity, plays a crucial role in the studied coopetition, in two ways (see Figure 1).

Figure 1. The reciprocal link between coopetition and territory

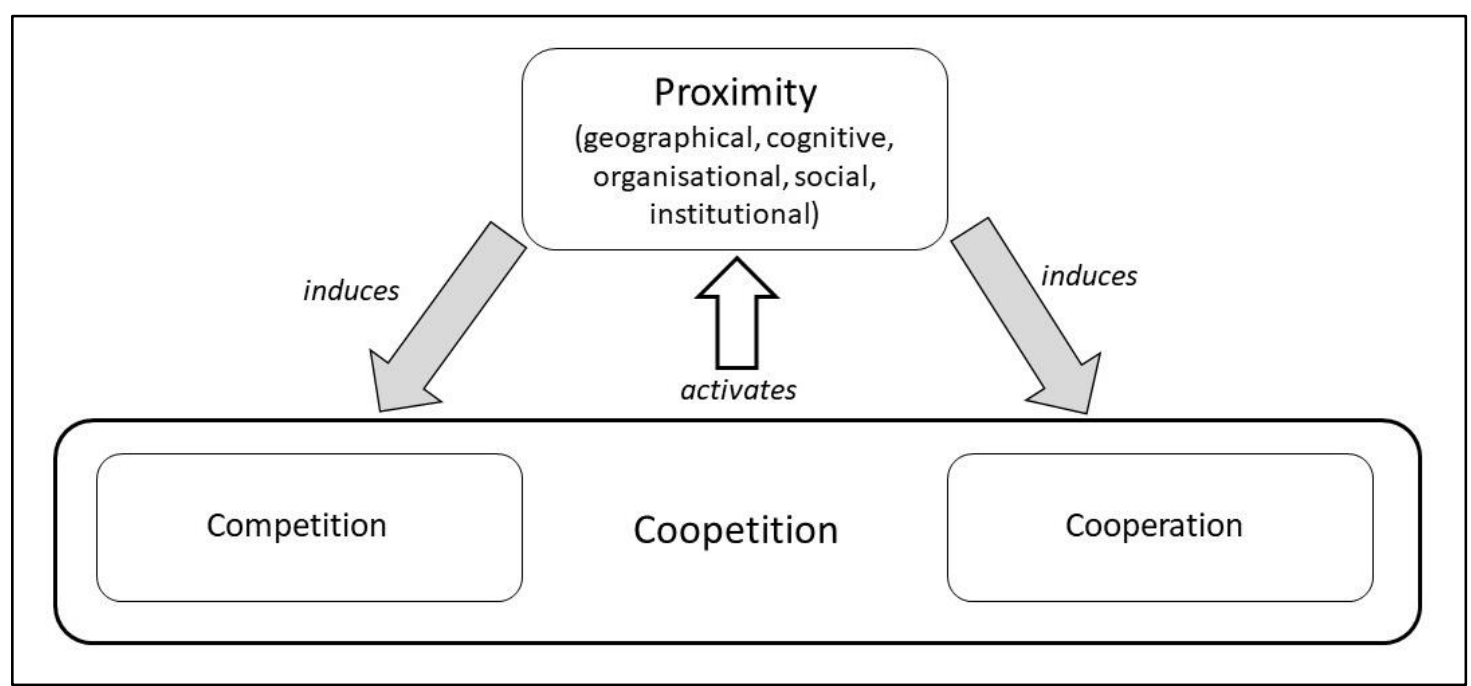

Source: authors

Firstly, proximity facilitates the implementation of coopetitive relationships between health institutions, by deepening cooperation and strengthening competition, i.e. inducing coopetition. The territory is therefore acting as a catalyst for coopetition. Secondly, reciprocity seems to be true: as Torre (2010) said, the different forms of proximity are neutral and can be activated or not, but also intended or endured. Here, 
coopetition appears to strengthen the different forms of proximity between actors, since it obliges - or encourages - them to be closer (in the five senses of the term) to each other. Therefore, coopetition and proximity are mutual catalysts. As the territory, which is a mix of five forms of proximity, induces coopetition among organisations located here, coopetition, in return, activates proximity between partners.

Our study raises several other points, based on previous literature. Firstly, the question of a more or less intentional coopetition is highlighted through our findings, as Mariani (2018) previously showed it. In the case of cancer treatment providers, the cognitive proximity leads sometimes to a spontaneous coopetition, for instance concerning research - because everyone benefits from it. Nevertheless, sometimes, it leads, too, to an enforced coopetition - when the Regional Health Service requires cooperation because of equipment permits, for instance. As for cognitive proximity, organisational proximity is sometimes spontaneous, i.e. on the initiative of the actors themselves, who implement partnership agreements, but, sometimes, it is decided by the Regional Health Service. Through our case study, coopetition appears to be a pretext for actors to strengthen their institutional proximity, too. They belong to the same industry, healthcare, and therefore share strong values. In reciprocity, institutional proximity seems to facilitate the implementation of coopetition, even when it is imposed by public authorities.

Secondly, social proximity highlights the question of different professional groups. These communities of practice clearly do not share the same languages, expectations or temporalities (Carlile, 2002). According to Star and Griesemer (1989), the aim is to build representations that allow cooperation between these social worlds. Coopetition then plays this role. It could be imposed through injunctions that do not leave the choice to individual actors, regardless of the world to which they belong. It 
could also be desired by the actors themselves, who then develop collaborations between institutions, most often inside one social world.

Thirdly, concerning the particular institution of Regional Health Service, it acts as a regulator, playing the role of a third party, initiating, developing and ensuring a balance in coopetitive relations, as the literature previously showed it (Kylänen and Rusko, 2011; Mariani, 2018). Therefore, it is important to note the key role of public authorities, which, as regulators, are essential in this industry.

Our contributions seem therefore valuable at a theoretical and empirical level. Concerning the coopetition literature, our research shows that the territory matters for coopetition and that, as a strategy implemented by organisations in a given industry, coopetition strengthens the different forms of proximity that make the territory exist. Regarding the healthcare sector, our study gives, first, an empirical evidence that coopetition is an appropriate strategy to better manage the current challenges of this industry. Second, we think it would help managers to identify the different levels of analysis and decision-making in a complex and uncertain environment, subject to strong pressure from public authorities, but also from the expectations of stakeholders, particularly patients and staff, who are mainly concerned with original charitable values.

\section{Conclusion}

While the literature on coopetition has been considerably enriched and structured in recent years, some theoretical gaps could be noted. This is the case of the role played by the territory in coopetitive relations, almost totally ignored by the literature, although varied in its subjects and objects. This article therefore contributes to fill this gap, by investigating the healthcare sector, more specifically the cancer treatment field on a 
local area. Through an analysis of coopetitive relationships through a reading grid consisting of the five dimensions of proximity - cognitive, organisational, social, institutional and geographical (Boschma, 2005) - this research shows that territory matters in coopetition, just as coopetition strengthens territory. In other words, the territory acts as a catalyst for coopetition, and, in reverse, the coopetitive relationships developed between the actors activate the different dimensions of proximity and thus contribute to the existence of the territory.

Our study is not without limits, first and foremost the very specific industry that is healthcare, thereby limiting the potential for generalization of the case. It should also be noted that the field of health is extremely broad, with numerous interactions between different public and private actors in a very complex managed sector. In addition, much remains to be done to better understand the links between each form of proximity and the coopetitive strategy put in place between organisations. This research is only a preliminary step in this direction, and will deserve to be extended by more targeted studies on each of the forms of proximity in order to better measure the impact and influence of each on coopetition.

Nevertheless, it seems to us that this work constitutes an important step in understanding the role of the territory in coopetition, which constitutes, more than ever, an essential element of context for organisations, regardless of their sector or size. From an empirical and managerial perspective, our work furthers the knowledge of coopetitive relationships between regional healthcare providers and gives an empirical evidence that the regional area is a catalyst for coopetition. 


\section{References}

Barretta, Antonio. 2008. "The Functioning of Co-Opetition in the Health-Care Sector: An Explorative Analysis." Scandinavian Journal of Management 24 (3): 209-20. https://doi.org/10.1016/j.scaman.2008.03.005.

Becattini, Giacomo. 1991. "Italian Industrial Districts: Problems and Perspectives." International Studies of Management and Organisation 21 (1): 83-90. https://doi.org/10.1080/00208825.1991.11656551.

Bengtsson, Maria, and Sören Kock. 1999. "Cooperation and Competition in Relationships between Competitors in Business Networks." Journal of Business and Industrial Marketing 14 (3): 178-94. https://doi.org/10.1108/08858629910272184.

Bengtsson, Maria, and Tatbeeq Raza-Ullah. 2016. "A Systematic Review of Research on Coopetition: Toward a Multilevel Understanding." Industrial Marketing Management 57: 23-39. https://doi.org/10.1016/j.indmarman.2016.05.003.

Blanquart, Corinne, and Valentina Carbone. 2014. "Collaborative Supply Chains and Environmental Awareness: A Typology in Terms of Proximity." Supply Chain Forum: An International Journal 15 (4): 28-41. https://doi.org/10.1080/16258312.2014.11517356.

Boschma, Ron. 2005. "Proximity and Innovation: A Critical Assessment." Regional Studies 39 (1): 61-74. https://doi.org/10.1080/0034340052000320887.

Bouncken, Ricarda B., Viktor Fredrich, Paavo Ritala, and Sascha Kraus. 2018. "Coopetition in New Product Development Alliances: Advantages and Tensions for Incremental and Radical Innovation.” British Journal of Management 29 (3): 391-410. https://doi.org/10.1111/1467-8551.12213.

Bourdillon, François. 2005. "Les Territoires de La Santé, Maillon Clé de l'organisation Sanitaire." Revue Française d'administration Publique 113 (1): 139. https://doi.org/10.3917/rfap.113.0139.

Brandenburger, Adam M., and Barry J. Nalebuff. 1995. The right game: Use game theory to shape strategy. Chicago: Harvard Business Review.

Carlile, Paul R. 2002. "A Pragmatic View of Knowledge and Boundaries: Boundary Objects in New Product Development." Organisation Science 13 (4): 442-55. https://doi.org/10.1287/orsc.13.4.442.2953.

Chakraborty, Samyadip. 2018. "Enablers of co-creation in hospital-supplier relationships: empirical study in Indian healthcare context." Supply Chain Forum: An International Journal 19 (4): 331-352. https://doi.org/10.1080/16258312.2018.1503921

Czakon, Wojciech, and Katarzyna Czernek. 2016. "The Role of Trust-Building Mechanisms in Entering into Network Coopetition: The Case of Tourism 
Networks in Poland." Industrial Marketing Management 57 (August): 64-74. https://doi.org/10.1016/j.indmarman.2016.05.010.

Czakon, Wojciech, Patrycja Klimas, and Marcello Mariani. 2019. "Behavioural Antecedents of Coopetition: A Synthesis and Measurement Scale." Long Range Planning. https://doi.org/10.1016/j.lrp.2019.03.001.

Dahl, Johanna, Sören Kock, and Eva Lena Lundgren-Henriksson. 2016.

"Conceptualizing Coopetition Strategy as Practice: A Multilevel Interpretative Framework." International Studies of Management and Organisation 46 (2-3): 94-109. https://doi.org/10.1080/00208825.2015.1093794.

Dana, Léo-Paul, and Hervé Dumez. 2015. "Qualitative Research Revisited: Epistemology of a Comprehensive Approach.” International Journal of Entrepreneurship and Small Business 26 (2): 154-170. https://doi.org/10.1504/IJESB.2015.071822.

Dorn, Stefanie, Bastian Schweiger, and Sascha Albers. 2016. "Levels, Phases and Themes of Coopetition: A Systematic Literature Review and Research Agenda." European Management Journal 34 (5): 484-500. https://doi.org/10.1016/j.emj.2016.02.009.

Fernandez, Anne Sophie., Paul Chiambaretto, Frédéric Le Roy, and Wojciech Czakon, W. (Eds.). 2018. Routledge Companion to Coopetition Strategies. Abingdon: Routledge.

Florida, Richard. 1995. “Toward the Learning Region.” Futures 27 (5): 527-36. https://doi.org/10.1016/0016-3287(95)00021-N.

Gee, E. Preston. 2000. “Co-Opetition: The New Market Milieu." Journal of Healthcare Management/American College of Healthcare Executives. http://www.ncbi.nlm.nih.gov/pubmed/11187357.

Gnyawali, Devi R., and Tadhg Ryan Charleton. 2018. "Nuances in the Interplay of Competition and Cooperation: Towards a Theory of Coopetition." Journal of Management 44 (7): 2511-34. https://doi.org/10.1177/0149206318788945.

Kirat, Thierry, and Yannick Lung. 1999. "Innovation and Proximity." European Urban and Regional Studies 6 (1): 27-38. https://doi.org/10.1177/096977649900600103.

Kylänen, Mika, and Rauno Rusko. 2011. "Unintentional Coopetition in the Service Industries: The Case of Pyhä-Luosto Tourism Destination in the Finnish Lapland." European Management Journal 29 (3): 193-205. https://doi.org/10.1016/j.emj.2010.10.006.

Le Roy, Frédéric, and Anne-Sophie Fernandez. 2015. "Managing Coopetitive Tensions at the Working-Group Level: The Rise of the Coopetitive Project Team." British Journal of Management 26 (4): 671-88. https://doi.org/10.1111/1467-8551.12095. 
Louazel, Michel, and Catherine Keller. 2016. 'Entre concurrence et coopération : un "effet bloc" des incitations règlementaires sur les relations entre établissements de santé ?'. In Management hospitalier et territoires : les nouveaux défis, edited by Olivier Baly et al, 195-218. Presses des Mines.

Mascia, Daniele, Fausto Di Vincenzo, and Americo Cicchetti. 2012. "Dynamic Analysis of Interhospital Collaboration and Competition: Empirical Evidence from an Italian Regional Health System." Health Policy 105 (2-3): 273-81. https://doi.org/10.1016/j.healthpol.2012.02.011.

Mariani, Marcello. 2016. "Coordination in Inter-Network Co-Opetitition: Evidence from the Tourism Sector." Industrial Marketing Management 53 (February): 10323. https://doi.org/10.1016/j.indmarman.2015.11.015.

Mariani, Marcello. 2018. "The Role of Policy Makers and Regulators in Coopetition". In Routledge Companion to Coopetition Strategies, edited by Anne Sophie Fernandez et al., 105-116. Abingdon: Routledge.

Pecqueur, Bernard. 2009. "De l'exténuation à La Sublimation : La Notion de Territoire Est-Elle Encore Utile?" Geographie, Economie, Societe, 11 (1): 55-62. Accessed March 13, 2019. https://www.cairn.info/revue-geographie-economie-societe-20091-page-55.htm.

Pecqueur, Bernard. 2015. "Evolution récente des dynamiques territoriales en France Vers un modèle productif territorialisé ?" In RH, RSE et territoires. Défis théoriques, réalisation pratiques, 15-32, Vuibert.

Peng, Tzu Ju Ann, and Mike Bourne. 2009. "The Coexistence of Competition and Cooperation between Networks: Implications from Two Taiwanese Healthcare Networks." British Journal of Management 20 (3): 377-400. https://doi.org/10.1111/j.1467-8551.2008.00565.x.

Porter, Michael E. 1993. The Competitive Advantage of Nations. Cambridge: Harvard Business School Management Programs.

Porter, Michael E. 1998. Clusters and the New Economics of Competition. Harvard Business Review 76(6), 77-90.

Porto-Gomez, Igone, Urko Aguirre-Larracoechea, and Jon Mikel Zabala-Iturriagagoitia. 2018. "Tacit Coopetition: Chimera or Reality? Evidence from the Basque Country." European Planning Studies 26 (3): 611-34. https://doi.org/10.1080/09654313.2017.1402866.

Rallet, Alain, and André Torre. 2004. "Proximité et Localisation." Économie Rurale 280 (1): 25-41. https://doi.org/10.3406/ecoru.2004.5470.

Soubeyran, Antoine, and Shlomo Weber. 2002. "District Formation and Local Social Capital: A (Tacit) Co-Opetition Approach." Journal of Urban Economics. Vol. 52: 55-92. www.academicpress.com. 
Star, Susan Leigh, and James R. Griesemer. 1989. "Institutional Ecology, 'Translations' and Boundary Objects: Amateurs and Professionals in Berkeley's Museum of Vertebrate Zoology, 1907-39.” Social Studies of Science 19 (3): 387-420. https://doi.org/10.1177/030631289019003001.

Torre, André. 2010. “Jalons Pour Une Analyse Dynamique Des Proximités.” Revue d'Économie Régionale and Urbaine juin (3): 409. https://doi.org/10.3917/reru.103.0409.

van den Broek, Judith, Paul Boselie, and Jaap Paauwe. 2018. "Cooperative Innovation through a Talent Management Pool: A Qualitative Study on Coopetition in Healthcare." European Management Journal 36 (1): 135-44.

https://doi.org/10.1016/j.emj.2017.03.012.

Westra, Daan, Federica Angeli, Martin Carree, and Dirk Ruwaard. 2017. "Coopetition in Health Care: A Multi-Level Analysis of Its Individual and Organisational Determinants." Social Science and Medicine 186: 43-51. https://doi.org/10.1016/j.socscimed.2017.05.051.

Yanamandra, Ramakrishna. 2018. "Development of an Integrated Healthcare Supply Chain Model." Supply Chain Forum: An International Journal 19 (2): 111-21. https://doi.org/10.1080/16258312.2018.1475823.

Yin, R K. 1999. "Enhancing the Quality of Case Studies in Health Services Research." Health Services Research 34 (5 Pt 2): 1209-24. http://www.ncbi.nlm.nih.gov/pubmed/10591280. 